\title{
Profile of Immunization Practice by General Practitioners and Pediatricians in Private Setting
}

\author{
Soedjatmiko, Hartono Gunardi, Hindra Irawan Satari, Adrian Himawan, Natharina Yolanda \\ Department of Child Health Faculty of Medicine Universitas Indonesia Jakarta
}

\begin{abstract}
Basic immunization coverage in Indonesia in 2013 was still low (59.2\%) (IBHS, 2013). Physicians' attitude and practice were among the determinant factors of a successful immunization program. This survey aimed to describe general practitioner's (GP) and pediatrician's attitude towards immunization and its coverage in private practices. This cross-sectional study was performed by distributing questionnaires consisting of 5 items on opinion and 10 items on immunization practices to 100 respondents in November 2014. Completed questionnaires were obtained from 29 GPs and 65 pediatricians. Most respondents considered that the Expanded Program in Immunization vaccine should be given. First dose of hepatitis B vaccine was mostly given in the first 12 hours after birth ( $90 \%$ GPs and $74 \%$ pediatricians). Oral polio vaccine was mostly given shortly before hospital discharge (65\% of GPs and $81 \%$ pediatricians) while the DTwP-HB-Hib vaccine were given by $27 \%$ of GPs and $21 \%$ of pediatricians to $>75 \%$ patients. Pneumococcal, rotavirus, hepatitis A, typhoid, and influenza vaccines were provided by less than $25 \%$ GPs and pediatricians, except for the influenza vaccine which was provided by $31 \%$ pediatricians. MMR vaccine was given to $>75 \%$ patients by $16 \%$ of GPs and $29 \%$ of pediatricians. This pilot survey of immunization practice in private setting might be the first study in Indonesia that this can be considered as a preliminary report of immunization in private setting. Further studies need to be done, especially regarding problems in immunization in private practices. [MKB. 2017;49(4):224-30]
\end{abstract}

Key words: Attitude, general practitioners, immunization practice, private setting, pediatricians

\section{Gambaran Praktek Imunisasi Dokter Umum dan Dokter Spesialis Anak di Praktek Swasta}

\begin{abstract}
Abstrak
Riset Kesehatan Dasar 2013 melaporkan bahwa cakupan imunisasi Indonesia masih rendah (59,2\%). Sikap dan praktik imunisasi dokter merupakan salah satu faktor penentu keberhasilan. Tujuan penelitian ini mengetahui sikap dokter dan cakupan imunisasi di praktik swasta. Penelitian potong lintang dilakukan dengan menyebarkan kuesioner tentang sikap dan praktik imunisasi kepada responden, yaitu 29 dokter umum (DU) dan 65 dokter spesialis anak (DA) pada bulan November 2014. Mayoritas responden berpendapat bahwa vaksin program pengembangan imunisasi harus diberikan. Vaksin hepatitis B dosis I mayoritas diberikan dalam 12 jam setelah lahir (90\% oleh DU dan 74\% oleh DA). Vaksin polio oral mayoritas diberikan sebelum pulang perawatan $(65 \%$ oleh DU dan 81\% oleh DA), Vaksin DTwP-HB-Hib diberikan oleh 27\% DU dan 21\% DA kepada $\geq 75 \%$ pasien. Penggunaan vaksin pneumokokus, rotavirus, hepatitis A, tifoid dan influenza pada $>75 \%$ pasien adalah kurang dari 25\%, kecuali vaksin influenza, yaitu 31\% digunakan oleh DA. Pemberian vaksin MMR pada $>75 \%$ pasien dilakukan oleh 16\% DU dan 29\% DA. Penelitian imunisasi pada praktik swasta ini mungkin merupakan laporan yang pertama dipublikasi di Indonesia. Penelitian lebih lanjut diperlukan untuk mengetahui hambatan imunisasi di praktik swasta. [MKB. 2017;49(4):224-30]
\end{abstract}

Kata kunci: Cakupan imunisasi, dokter, imunisasi, praktik, spesialis

Correspondence: Dr. Hartono Gunardi, dr., Sp A(K), Department of Child Health Faculty of Medicine Universitas Indonesia, Jakarta,E-mail: hartono@ikafkui.net 


\section{Background}

Immunization is an effective measure to prevent vaccine preventable diseases. Indonesian Basic Health Research in 2013 showed that the coverage of complete primary immunization in Indonesia was only $59.2 \%,{ }^{1}$ while the goal of the Global Immunization Vision and Strategy during 2006-2015 was at least 90\% national vaccination coverage and at least $80 \%$ coverage in every district. ${ }^{2}$

Several factors might play a role, such as parental knowledge and attitude, physician attitude. An important factor that influence the immunization coverage is the attitude of medical staffs regarding immunization, especially general practitioners (GPs) and pediatricians. Previous studies showed that immunization by family doctor was influenced by their knowledge and attitude toward immunization and the preventable diseases. ${ }^{3}$ The objective of this study was to explore physician attitude and immunization coverage in private practices.

\section{Methods}

This study was a descriptive, cross-sectional study. The study was done by distribution of questionnaires to GPs and pediatricians who voluntarily agreed to participated. Minimal sample size was calculated by formula for qualitative study: Z 1- $\alpha / 2^{2} \mathrm{p}$ (1- p) $\mathrm{d}^{-2}$, while $\alpha=0.05, \mathrm{Z} 1-\alpha / 2=1.96$. P was the expected proportion in population $=0.5$ and $\mathrm{d}$ was absolute error $=0.1 .^{4}$ Then minimal sample size was 96. Respondents were participants of $67^{\text {th }}$ Continuing Medical Education organized by Department of Child Health, University of Indonesia in Jakarta on November $17^{\text {th }}, 2014$. Inclusion criteria was GPs or pediatricians who gave consent to participate and complete the questionnaire. Exclusion criteria were health profesionals other than GPs or pediatricians and incomplete answer $(>20 \%$ unanswered questions).

The questionnaire, which had been tested for understandability and applicability among pediatric residents, was consisted of 5 questions regarding opinions about Haemophilus influenza B (Hib), pneumococcus, rotavirus, measles-mumps-rubella (MMR), and human papilloma virus (HPV) immunizations. The other 15 questions were assessing the respondents' knowledge about the timing of first dose of hepatitis $\mathrm{B}$, polio vaccine in neonates and the frequencies of some vaccines given to their patients (DTwP-HB-Hib, pneumococcus, rotavirus, MMR, hepatitis A, typhoid, influenza, HPV). The frequencies of each immunization was rated as never, $<25 \%, 25-50 \%, 50-75 \%$, and $>75 \%$ of patients. The cut-off was arbitrarily set to quantify the immunization coverage. Data from questionnaires were presented in tables.

Table 1 Respondents' Characteristics

\begin{tabular}{lccc}
\hline \multicolumn{1}{c}{ Characteristic } & $\begin{array}{c}\text { General } \\
\text { Practitioner }\end{array}$ & Pediatrician & Total \\
\hline $\begin{array}{l}\text { Age (year), median (range) } \\
\text { Sex }\end{array}$ & $26(24-70)$ & $47(31-75)$ & - \\
$\quad$ Male & 9 & 23 & 32 \\
$\quad$ Female & 20 & 42 & 62 \\
Domicile & & & 75 \\
$\quad$ Java island* & 24 & 51 & 19 \\
$\quad$ Outside of Java island** & 5 & 14 & 48 \\
Practice duration (years) & & & 26 \\
$\quad<5$ & 23 & 25 & 20 \\
$\quad$ 5-20 & 2 & 22 & 113 \\
$\quad>20$ & & 18 & 4 \\
Practice location*** & 28 & 85 & 1 \\
$\quad$ Private hospital/clinics & 3 & & \\
$\quad$ Governmental hospital/clinic & 25 & \\
\hline
\end{tabular}

*Jakarta, Bogor, Depok, Tangerang, Banten, West Java, Middle Java, East Java; **Bali, Aceh, Sumatera Utara, Riau Islands, Riau, Bengkulu, Lampung, West Borneo, Middle Borneo, East Nusa Tenggara, Maluku, Papua; ${ }^{* * *}$ Respondents could answer more than 1 answers 


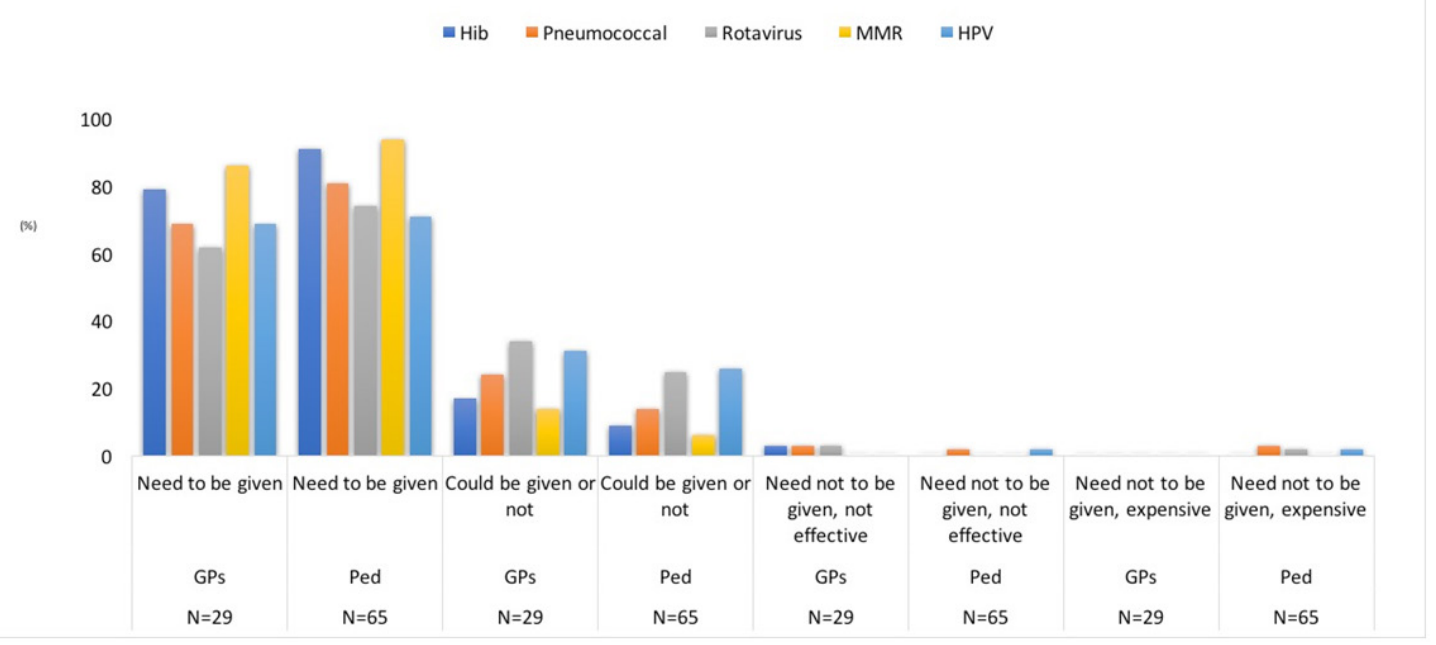

Figure 1 Respondent's Attitude Regarding Some Vaccines

\section{Results}

There were 100 questionnaires distributed to the participants; 98 participants returned the questionnaire. Four participants were excluded due to incomplete questionnaire filling $>$ and 47 (31-75) years old, respectively. Respondents' characteristics were $20 \%$ of the questions; the remaining 94 questionnaires were analyzed. Respondents were 29 GPs and 65 pediatricians, with median age of 26(24-70) years old. Majority of respondents were originated from Java islands (75 participants) especially from Jakarta (17 GPs and 37 pediatricians). Most of the GPs (48.9\%) and pediatricians $(38.5 \%)$ had been practicing medicine for up to 5 years (Table).

Majority of respondents stated that some nonEPI vaccines had to be given, such as Hib (79\% of
GPs and $91 \%$ of pediatricians), pneumococcus ( $69 \%$ of GPs and $81 \%$ of pediatricians), rotavirus ( $62 \%$ of GPs and $74 \%$ of pediatricians), MMR ( $86 \%$ of GPs and $94 \%$ of pediatricians), and HPV ( $69 \%$ of GPs and $71 \%$ of pediatricians). Some respondents (3\% of GPs and $3 \%$ of pediatricians) stated that certain non-EPI vaccines need not to be given because they were less effective or expensive (Fig 1).

As much as $90 \%$ of GPs and $74 \%$ of pediatricians stated that they gave the first dose of hepatitis $B$ vaccine in the first 12 hours after birth. About $11 \%$ of pediatrician administered hepatitis B vaccine beyond 24 hours compared to 3\% of GP (Fig 2.1) Most of the GPs and pediatricians had given hepatitis B immunoglobulin (HBIg) in $>80 \%$ of babies with HBsAg-positive mothers (Fig 2).

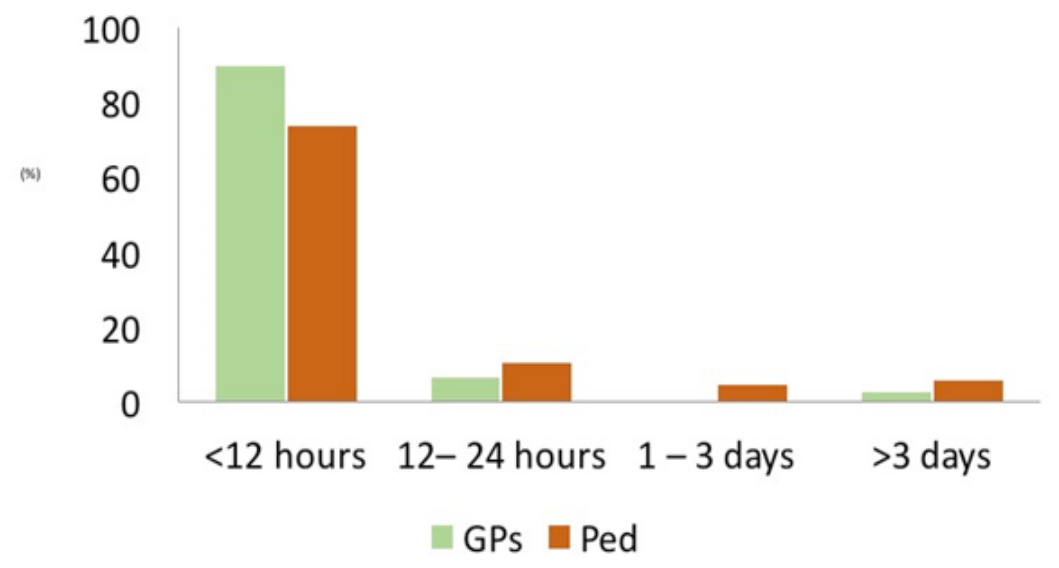

Figure 2 Timing of First Dose Hepatitis B Vaccine 


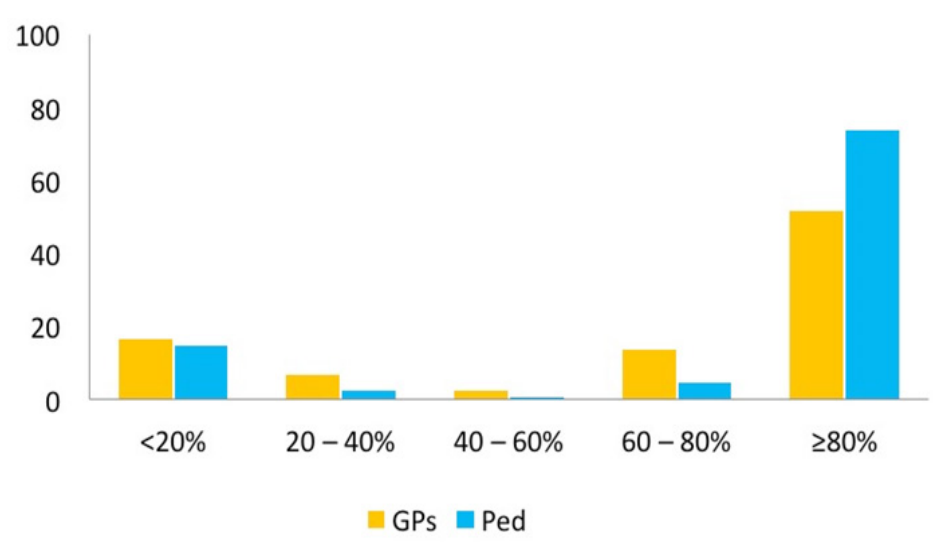

Figure 3 Timing of HBIg Administration in Babies Born to HBsAg+ Mothers

As much as $65 \%$ of GPs and $81 \%$ of pediatrician had given oral polio vaccine (OPV) shortly before babies were discharged from hospital. Aproximately 24\% of GPs and 8\% of pediatricians administered OPV immediately after birth. Most of the GP never use inactivated polio vaccine; whereas $37 \%$ of pediatrician had used it in $\geq 75 \%$ of their patients (Fig 4 ).

The usage of DTwP-HB-Hib vaccine in $>75 \%$ of patients was only found in $27 \%$ of GPs and $21 \%$ of pediatricians. The usage of pneumococcus and rotavirus was low. Some GPS (45\%) never use pneumococcal vaccine and $25 \%$ of pediatricians had used it in $<25 \%$ of their patients. Rotavirus vaccine had never been used in $52 \%$ of GPs and only $18 \%$ of pediatricians used it in $>75 \%$ of their patients. The usage of MMR, hepatitis A, typhoid, influenza vaccine in $>75 \%$ patients was a little bit higher in pediatrician group versus GPs, except for HPV vaccine; but the usage percentage was still under 30\% (Table 4). About $58 \%$ of GPs and $52 \%$ of pediatricians had never given HPV vaccine to their patients (Fig 5). Thermometer in refrigerators used to monitor vaccines was reported in $92.5 \%$ of GPs and $80.3 \%$ in pediatricians' practice places.

\section{Discussion}

Respondents in this study were originated from various regions in Indonesia, so it could represent attitude toward immunization practice. All GPs and $98.9 \%$ of pediatricians had more than a year experience, then most respondents should have appropriate experience in immunization.

Most of GPs and pediatricians gave hepatitis B immunization in the first 12 hours after birth, but

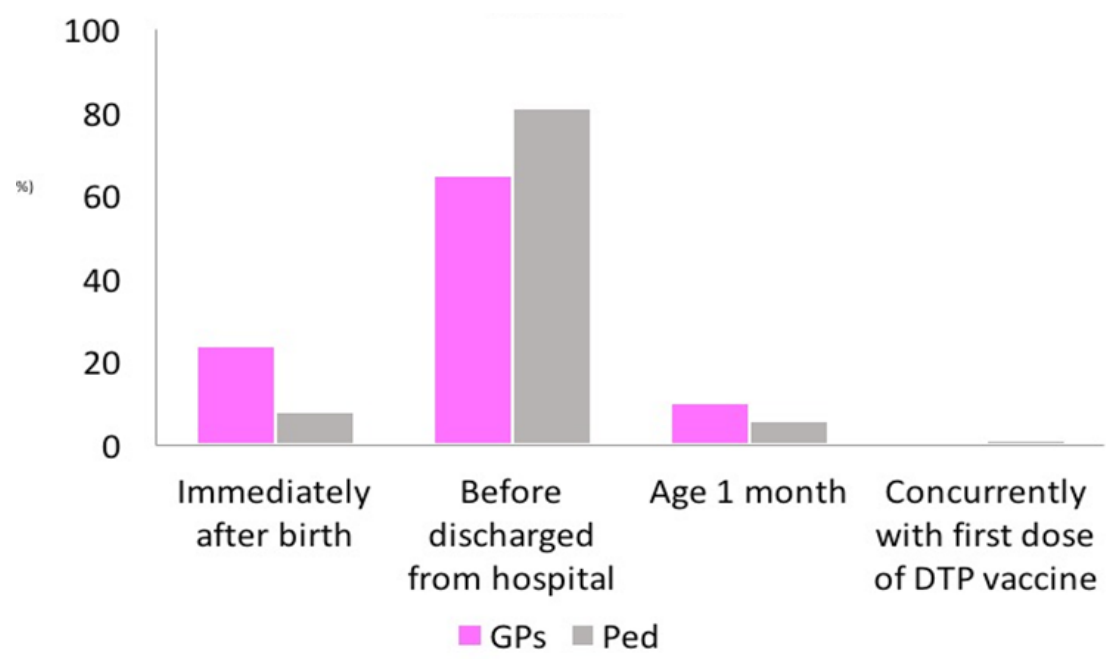

Figure 4 Timing of First Oral Polio Vaccine 


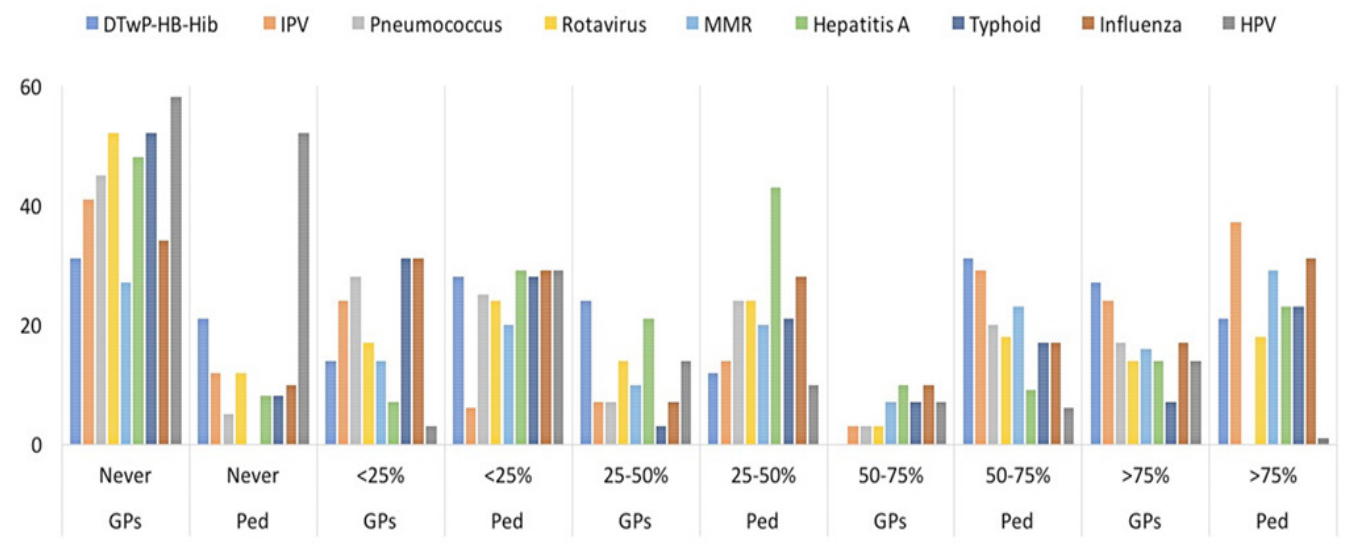

Figure 5 Vaccine usage by General Practitioners and Pediatricians

$11 \%$ of pediatricians and $3 \%$ of GPs administered hepatitis B vaccine beyond 24 hours after birth. Hepatitis B vaccine was recommended to be given within 12 hours by Indonesian Pediatric Society, ${ }^{2-5}$ or at least within 24 hours after birth as recommended by World Health Organization. ${ }^{3-6}$ Perinatal HB transmission carries high risk of chronic hepatitis B that may lead to hepatocellular carcinoma which can be prevented by HB vaccine given in first 24 hours. . $^{-}$ 7 Fortunately, HBIg has been administered by majority of GPs and pediatricians for babies born to HBsAg-positive mother. If pregnant women are not screened for HBV marker, all infants should receive birth dose HB vaccine in 24 hours, then at one and six months of age ${ }^{4}$ or at 2, 3, 4 months with combined DTP vaccine..$^{3-6}$ Effectiveness study of hepatitis B immunization without HBIg to prevent vertical transmission in infants born to HBsAg positive mother in Jakarta was between $70-90 \% .^{5-8}$ This data showed the importance of private practice to increase birth dose HB immunization coverage as Indonesia is classified as intermediate to high endemicity for hepatitis B infection. ${ }^{6-9}$

Birth dose OPV was given immediately after birth by $24 \%$ of GPs and $8 \%$ of pediatricians. This immediate immunization was appropriate for babies delivered at home. If the baby was delivered in maternity hospital or general hospital, then the birth dose OPV should be given before discharge to prevent spreading of live attenuated polio virus in OPV through fecal excretion. This correct timing of OPV administration had been practiced by $65 \%$ of GPs and $81 \%$ of pediatricians in our study.

DTwP-HB-Hib immunization coverage- which was recommended by Indonesian Health Ministry-was also low in this study. Based on 2013 Indonesian Basic Health Research, primary series of DTP-HB3 had the lowest coverage among primary vaccines $(75.6 \%) .{ }^{1}$ A survey in India stated that $64.5 \%$ of pediatricians used $\mathrm{Hib}$ vaccine routinely and $31.5 \%$ used it selectively. In that survey, pediatricians were found to have enough knowledge regarding potential diseases caused by Hib would be 2.42 times more frequent to give Hib immunization. Doctors who believe in high efficacy of Hib vaccine was 4.74 times more frequent to give immunization. ${ }^{7-10}$ This data showed that physicians' attitude and knowledge contributes to immunization coverage.

Majority ofGPs (69\%) and pediatricians (81\%) were both agree that pneumococcal vaccine need to be given. It had not been used widely by GPs, though it was used in $<25 \%, 25-50 \%, 50-75 \%$ coverage by $25 \%, 24 \%$ and $20 \%$ pediatricians respectively. An explorative study in India showed that majority of pediatricians $(67.7 \%)$ recommended pneumococcal conjugate vaccine (PCV) to all patients. Immunization was easily accepted in India because patients understood and were well informed about immunization due to counseling and recommendation by pediatricians. Majority of pediatricians agreed to implement PCV into universal immunization program. From that survey, it was reflected that pediatricians have big role in increasing pneumococcal immunization coverage..$^{8-11}$

Majority of GPs (62\%) and pediatricians $(74 \%)$ agreed that rotavirus vaccine needed to be given but majority of GPs (52\%) had never used it and pediatricians had used it with variable frequency. A survey in India showed that majority 
of pediatricians used rotavirus vaccine in $80.2 \%$ of their patients. Knowledge and attitude about potential diseases caused by rotavirus were not associated with the immunization practice ${ }^{7-10}$ as also found in this study. In Asia Pacific countries including Indonesia, rotavirus vaccine usage was low, except for Australia who had implemented rotavirus into their national program. Rotavirus immunization coverage in Indonesia was only $<5 \%$. Rotavirus vaccine usage in Pacific Asian countries was mainly used in private clinic.9-12

Hepatitis A immunization by GPs and pediatricians varied in coverage. In Asia Pacific countries, only Australia that had implemented hepatitis A immunization into their national program. ${ }^{9-12}$

About $52 \%$ and $34 \%$ of GPs had never given typhoid and influenza immunization while $92 \%$ and $90 \%$ pediatricians had administered them respectively.

MMR immunization had been given by $73 \%$ of GPs and all pediatricians had administered MMR to their patients with varied coverage. This result was similar to a survey in US which stated that $84.9 \%$ of family doctors gave MMR immunization routinely in practice..$^{5-8}$

Majority of GPs and pediatricians never used HPV vaccine. Factors influencing HPV vaccine usage were parental attitude, gender of the doctor, knowledge about HPV, and the trust to medical institution.11,12- ${ }^{14,15}$ Doctors are the most appropriate person to educate parents and grow trust. Demonstrating a willingness to listen respectfully, encouraging questions, and acknowledging concerns are essential elements. Providing accurate information about risks and benefits is crucial to maintaining parental trust. ${ }^{13-16}$

In our study, $7.5 \%$ of GPs and $19.7 \%$ of pediatricians did not have thermometer in vaccine refrigerators. A survey of thermometer availability in 7 provinces in Indonesia reported that $87 \%$ primary health centers had thermometer in vaccine refrigerator. ${ }^{14-}{ }^{17}$ Lack of thermometer also found in developed country such as Korea that showed vaccine storage practice and healthcare providers' awareness regarding the cold chain was still low. This could be improved by education and policy making regarding vaccine storage which increased thermometer availability from $87.2 \%$ to $92.3 \%{ }^{15-}$ ${ }^{18}$ A similar study in Malaysia showed that attitude change after education could remain for 1 year after education. ${ }^{16-19}$ Therefore, education and policy making by government could improve vaccine storage practices.
There were several limitations in this study. The questionnaire was answered based on recall memory of GPs and pediatricians, which might cause recall bias and might not represent the real data. We did not explore the socioeconomic status of the GPs' and pediatricians' patients, which might effluent the affordability of vaccines. Furthermore, the respondents might not represent Indonesian GPs and pediatricians in general. However, this study might be the first report of immunization practice in private settings in Indonesia which could be beneficial to improve GPs and pediatrician attitude and immunization practice especially in private settings.

In general, pediatricians attitude was better to $\mathrm{Hib}$, pneumococcal, rotavirus, MMR and HPV vaccine than GPs. First dose of hepatitis B vaccine usage in the first 12 hours was better in GPs than pediatricians. Proportion of GPs used OPV immediately after birth was greater than pediatricians; this could reflect the lack of understanding in GPs about the risk of OPV administration to babies before discharged.

Despite the high awareness of GPs and pediatricians about the importance of immunization, the usage rate $>75 \%$ of DTwP-HBHib and non-EPI vaccines (e.g. pneumococcal, rotavirus, MMR, hepatitis A, typhoid, influenza, and HPV) was only found in $7-27 \%$ of GPs and $0-29 \%$ of pediatricians. Further study should be carried out to determine the factors associated with low immunization rates, especially non-EPI vaccines.

\section{References}

1. Indonesian Ministry of Health. Basic Health Research 2013. Jakarta: Indonesian Ministry of Health; 2014.

2. Globalvaccineaction plan2011-2020.Geneva: World Health Organization; 2013. [Accessed Dec 10, 2017]. Available from: http://www. who.int/iris/bitstream/10665/78141 /1/9789241504980_eng. pdf.

3. Collange $F$, Verger $P$, Launay 0 , Pulcini C. Knowledge, attitudes, beliefs and behaviors of general practitioners/family physicians toward their own vaccination: A systematic review. Hum Vaccin Immunother. 2016;12(5):1282-92.

4. Charan J, Biswas T. How to calculate sample size for different study designs in medical research?. Indian J Psychol Med. 2013;35(2): 121-6. 
5. Indonesian Pediatric Society Immunization Schedule Recommendation 2017 [Accessed Dec 10, 2017] Available at: http://www. idai.or.id/artikel/klinik/imunisasi/jadwalimunisasi-2017

6. World Health Organization. Summary of WHO position papers-recommendations for routine immunization. Updated March 2017. [Accessed on June 12, 2017]. Available at http://www.who.int/ immunization/ policy/Immunization_routine_table 1 . pdf?ua $=1$

7. World Health Organization. Hepatitis B vaccines: WHO position paper-July 2017. Wkly Epidemiol Rec. 2017;92:369-92.

8. Fitria L, Gunardi H, Akib AAP. Influence of Hepatitis B immunization to prevent vertical transmission of Hep-B virus in infants born from Hep-B positive mother. Paediatr Indones. 2010;50:321-5.

9. Yano Y, Utsumi T, Lusida MI, Hayashi Y. Hepatitis B virus infection in Indonesia. World J Gastroenterol. 2015;21:10714-20.

10. Gargano L, Thacker N, Choudhury P, Weiss P, Pazol K, Bahl S, et al. Predictors of administration and attitudes about pneumococcal, Haemophilus influenzae type $\mathrm{b}$ and rotavirus vaccines among pediatricians in India: a national survey. Vaccine. 2012;30(24):3541-5.

11. Zodpey S, Farooqui H, Chokshi M. Pediatrician's perspective on pneumococcal conjugate vaccines in India: an exploratory study. Value Health 2014;17(7):A685.

12. Lu C, Santosham M. Survey of national immunization programs and vaccine coverage rates in Asia Pacific countries. Vaccine. 2012;30:2250-5.

13. Campos-Outcalt D, Jeffcott-Pera M, CarterSmith P, Schoof B, Young H. Vaccines provided by family physicians. Ann Fam Med 2010;8:507-10.

14. Nikolic Z, Matejic B, Kesic V, Marinkovic J, Vranes A. Factors influencing the recommendation of the human papillomavirus vaccine by Serbian pediatricians. J Pediatr Adolesc Gynecol 2015;28(1):12-8.

15. Wong MCS, Lee A, Ngai KLK, Chor JCY, Chan PKS (2013) Knowledge, attitude, practice and barriers on vaccination against human papillomavirus infection: a cross-sectional study among primary care physicians in Hongkong. PLoS ONE. 2013;8(8):e71827

16. DiekemaDS.Improving childhoodvaccination rates. N Engl J Med. 2012;366(5):391-3.

17. Anggraini $A B$, Fitriati N. Electricity and risk of public health center had measles vaccine damage in Indonesia. Health Sci J Indones. 2015;6:116-20

18. Lee S, Lim H-S, Kim O, Nam J, Kim Y, Woo $\mathrm{H}$, et al. Vaccine storage practices and the effects of education in some private medical institutions. J Prev Med Public Health. 2012;45(2):78-89.

19. Gopal-Krishnan S, Sondi Sararaks A-SH, Amir LE, Ibrahim MY, Praim RK, Singh MA, et al. Vaccine storage in private practice: a community trial. J Family Med Community Health. 2014;1(2):1011. 